\title{
E-learning Portal Tools for Medical Education
}

\section{Magdalena Roszak ${ }^{1}$, Barbara Kołodziejczak ${ }^{1}$, Wiesław Półjanowicz ${ }^{2}$,} Andrzej Bręborowicz ${ }^{3}$, Anna Ren-Kurc ${ }^{4}$, Wojciech Kowalewski ${ }^{4}$

1 Department of Computer Science and Statistics, Poznan University of Medical Sciences, Poland

2 Department of Didactics and Modern Technologies in Education, University of Bialystok, Poland

3 Department of Pathophysiology, Poznan University of Medical Sciences, Poland

${ }^{4}$ Faculty of Mathematics and Computer Science, Adam Mickiewicz University in Poznań, Poland

\begin{abstract}
The necessary prerequisites for efficiently pursuing distance learning include carefully planned organization of work and resource management tools, typically found in an internet application - a distance learning portal. The portal application must meet a number of capacity and functionality requirements. Learning goals are pursued through implementation of appropriate tools available in the portal. In the article that follows, the authors attempt to analyze this aspect of medical education as utilized by blended learning and e-learning classes. The article presents a proposal for a set of tools to organize classes in an e-learning portal at a medical school. In addition, the article presents the opinions of students of the Poznan University of Medical Sciences and the Medical University of Bialystok who took part in distance education classes.
\end{abstract}

\section{Introduction}

Distance learning (Clarke, 2007; Hyla, 2012; Smyrnova-Trybulska, 2009) in medical education is achieved primarily with such methods as e-learning and blended learning, and is supported with m-learning (Meger, 2010). The necessary prerequisites for efficiently pursuing these learning formats include carefully planned organization of work and resource management tools, typically found in an internet application - a distance learning portal (Roszak et al., 2014).

A portal is an extensive internet application which, apart from its ability to display a variety of information, offers various convenient options for the user, such as personalization of page appearance, a Web page search 
engine, file downloading, mail, a discussion forum, or chat capability. An educational portal is an example of a specialized portal with functionalities aimed at distance teaching. Learning goals are pursued through implementation of appropriate tools available in the portal. Thus, the portal application must meet a number of capacity and functionality requirements. Specification and analysis of these needs, taking into consideration the requirements arising from the qualification of medical learning, is of crucial importance and requires proper knowledge and experience (Roszak et al., in press).

One of the significant aspects to be taken under consideration is the analysis of functions necessary for proper management of courses and user accounts in the e-learning portal, i.e., managing learning groups, inclusion of communication tools, examining and surveying, participation in knowledge building, and archiving resources. In the article that follows, the authors attempt to analyze this aspect of medical education on the basis of blended learning and e-learning classes. This may help medical universities starting to offer remote classes to select an appropriate educational portal. The article presents a proposal for a set of tools to organize classes in an e-learning portal at a medical school. The results are based on two editions of pathophysiology courses held at the Poznan University of Medical Sciences for Polish-language students of the medical faculty during the academic years 2013-2014 and 2014-2015 (e-learning portal: OLAT - Online Learning And Training), and are supported by assessments of classes held for therapeutic massage and obstetrics, gynecology, and gynecological and obstetric nursing at the Medical University of Bialystok for Polish-language students of the obstetrics and physiotherapy faculties during the 2011-2012 academic year (e-learning portal: Moodle). In addition, the article presents opinions of students who took part in distance education classes and valued them very highly. The results of surveys show their expectations, which indicate that teaching staff should continue their distance education undertakings.

During their research, and while teaching classes at medical schools, the authors used the research results available in literature as well as their 10-year experience in distance learning (in science and humanities) and implementation of e-learning portals at universities in Poznan and Bialystok.

\section{Characteristics of Classes at a Medical School}

In the opinion of the authors of this article, in order to characterize classes in basic subjects at a medical school, attention should be paid to certain important aspects of their organization, such as: 
1. Division into student groups.

2. Different times of classes for particular groups.

3. Students switching groups during the course.

4. Initial tests.

5. Passing tests and exams.

6. Retesting and retaking exams.

7. Form of class (lecture, practical class, seminar, lab class, clinical class, projects).

8. Several teachers teaching the classes of a single subject.

9. Several teachers lecturing on the subject but not necessarily teaching other classes within the course.

10. Cooperation with administrative personnel supporting class organization.

11. Professional coordination by subject head and overseeing of course execution.

\section{Description of Traditional Classes of a Pathophysiology Course}

Classes in pathophysiology take place within a specified time frame with groups of students determined by the school. As soon as one group completes their course, the next group follows. Classes are taken by approximately 250 students during one semester. The course consists of lectures and seminar classes. The course subject is divided into 10 units taught by 7 teachers, most of whom also deliver lectures in their respective fields of study.

Seminar classes start with a test to determine baseline knowledge; after completion of classes, each group of students takes a final test. An exam takes place when all the groups have taken their classes. A student who fails to pass the final test during the semester has the right to retake the test twice. Without passing the test, they cannot take the exam. There are two exam dates chosen by students at their discretion. These are followed by two retake dates for those who failed to pass the exam at first.

All final test and exam dates are determined in agreement with the students, which is coordinated by an administrative employee. Knowledge is evaluated traditionally - tests are printed and verified by hand. Results are usually saved in a worksheet and sent to students via e-mail within 5 days of the test date.

Information concerning class organization, i.e., conditions for passing, topics, course schedule, and basic learning resources are usually made available on a website. 
Teachers can be consulted on the school site at specified times. Communication regarding course organization takes place by phone, via group prefects, via e-mail, or at meetings in school buildings.

\section{Use of E-learning Portal: Classification of Tools - the Authors' Proposal}

Blended learning seems to be a natural option for teaching at a medical school. This method emphasizes the role of the teacher (master) in the learning process, while at the same time matching the expectations of generations raised with high technologies. Students participate in local classes at the school and work remotely with the e-learning portal. Taking into account the characteristics of medical education, the authors suggest that the learning portal be viewed as an application for:

a. presentation of learning resources,

b. communication,

c. examination and surveying,

d. managing course organization (distribution of information),

e. archiving learning results.

The above list defines the functions that must be covered by e-learning portal tools.

Students take a remote course available to them on the portal and moderated by teachers according to the rules defined in the course regulations. After the end of the course and after passing the exam, the student (learner) is no longer entitled to access the course and its resources. Knowledge providers, i.e. persons involved in teaching the course (chapter: Characteristics of Classes at a Medical School, points 8-11), constitute separate groups of portal users, with different resource access permissions.

Both blended learning and e-learning at medical schools have been evolving during recent years, taking on various different forms (Półjanowicz, 2014). Research supports the need not only for their implementation, but also for their high efficiency in achieving learning goals.

According to the authors' experience and studies, medical students at Polish schools are more willing to advocate blended learning than e-learning. However, we should bear in mind that this is a result of the small number of distance education classes, as well as a deeply rooted tradition of teaching in a master-learner system. 


\section{E-learning Portal Tools For Teaching Classes at a Medical School}

The main function of an e-learning portal is to build, gather, and distribute courses containing such learning resources as text, images, animations, sound, or video. When analyzing this aspect, we should emphasize the ability to clearly divide the subjects covered into separate course components (nodes) that make up a separate space with tools for the topic. It should be remembered that the learning resources of a distance course may - and should - be modified during the course. Thus, an e-learning portal must offer options for flexible and relatively rapid action in this respect, while criteria of assessment and evaluation, which are defined at the beginning of the distance course, are preserved and will not change as the course is conducted.

Preparation of learning resources. The primary technology applied in creating materials is the formatting of text and graphics in HTML, with possible extensions allowing multimedia to be played safely: FLASH, JAVASCRIPT, etc. Various specialized editors are used to create files according to these standards. For the subject under review, the files were multimedia presentations aiming to prepare students for traditional seminar classes and clinical cases.

File repositories. Some materials within the pathophysiology course were made available for printing as files placed by the teacher in the subject directory (file repository for the subject course). In addition, each student was able to check the level of their course knowledge by completing self-tests. Asynchronous communication via e-mail (contact form within the course) and a discussion forum, used exclusively for discussing the subject matter, were used to communicate with the teacher.

Lectures. There was a separate space within the pathophysiology course dedicated to lectures, which were delivered locally. Before every lecture, printable materials were made available in the portal, to be used as a basis for students' notes. After the end of the actual lecture, presentations used by the lecturer were placed in the portal.

Additional distance repetition courses. In cases where a course is held for a large group of students, there may be some students representing a lower level of initial knowledge necessary for taking part in the class. If the teacher notes such differences during local classes, they may suggest improvement using remote repetition courses in selected topic areas. It would be reasonable to group such repetition courses as available for a specific group of students but invisible for others, which would facilitate course navigation. This aspect is related to the portal's grouping mechanism. 
To sum up, every course unit has a separate structure (node) within the course and has the following tools available:

- a folder (file repository),

- a forum,

- a contact form (e-mail),

- testing,

- grouping students into new sub-groups.

Communication. Asynchronous communication will usually be used to communicate with the teacher for distance courses, via e-mail and a discussion forum used for discussing the subject matter only. The student must be informed in the course syllabus about the appropriate forms of contact. Apart from subject-matter issues, various kinds of organizational information are important for learners. These are covered by a separate forum, which is usually the group forum, or the general forum of the entire course. Subject-matter discussions should not be mixed in discussion forums with course organization issues. With the asynchronous character of the forum, discussions must be kept in order, as without such order users would frequently fail to remember the previous posts and they would be unable to classify them correctly in order to write a post concerning course content.

Discussion forum - summary. The process of acquiring and enhancing knowledge incorporates the ability of sharing one's knowledge with others. This is offered by discussion tools - a group or course forum. The teacher should be the initiator and often a moderator of such undertakings. Elearning portals provide tools for building various types of forums, such as: forums facilitating a simple discussion on one subject, general discussion boards accessible to all, or file dialogs.

E-mail. One of the possibilities for communication between course participants is sending messages to a given group (or several groups) or selected group members via e-mail in the e-learning portal. A message sent from the portal will reach the user's inbox. These inboxes, both assigned to students and teachers, should be set up on the school server to ensure communication security and confidentiality of school-student correspondence. This important requirement is often underappreciated. In addition, it is necessary to divide course participants into groups - student groups, teacher groups, or other groups established throughout the course (e.g. project groups).

The course for medical students considered here had a separate teacher contact form for every subject. In addition, the course had a general contact form available for communication with technical personnel responsible for portal service, who ensured its fault-free operation on a $24 / 7$ basis. 
In summary, the following tools are used for student-teacher communication:

- course forum,

- organizational forum,

- teacher contact form (e-mail),

- general (organizational) administration contact form,

- ability to group users within the portal for efficient communication through contact forms.

Evaluation of knowledge. Test or exam organization is an important part of learning. Apart from evaluating students' knowledge, classes should be evaluated as well (surveying). An electronic survey is a version of a test with different - slightly narrower - test logics. Electronic evaluation of knowledge can be carried out in various forms, such as: tests with closed-ended questions, tests with open-ended questions, group projects, and open tasks. At a medical school, tests with closed-ended questions are usually used. This stage of education, whether traditional or digital, always involves a lot of effort. This is particularly true when examination is combined with the surveying of a large group of students, and testing/retesting must be repeated at several different dates.

For the pathophysiology course, knowledge evaluation is comprised of 9 tests: 1 initial test, 3 course tests (including 2 retests), 1 lecture test, 2 different exam dates of which each student will choose one, and 2 exam retake dates. Testing takes place for a group of 250 students, while only a fraction of those students retake tests and exams. Thus, a school unit must face a major organizational challenge in managing the process of evaluating students' knowledge while surveying such a group of persons.

Integrated test editors. In the examination process using an e-learning portal, the most important aspect is the database of questions, produced once and used by the machine to pick questions in a random order according to rules defined by the teacher. Every student receives an individual exam set with a random order of questions and random order of answers. Test duration is counted asynchronously - equally for each tested person. After the end of the test, the participant knows the score, receives feedback as to whether or not they passed the exam, and the whole process is archived automatically. Detailed test results are available for the teacher divided by group and course structure, in a format that can be saved on external storage media. Most e-learning portals offer tools for simple addition of questions with graphics or even multimedia, enabling one to pursue evaluation of knowledge in a highly efficient manner. International stan- 
dards for knowledge evaluation should be used - IMS Question and Test Interoperability (v.2.1 Final Specification).

Registration for an exam. For medical students, two exam dates are usually offered and each student must register for one of those dates. The same usually applies to other tests and retests. With e-learning portals, this process can proceed automatically. Registrants automatically create a new learning group to which a test will be offered by the teacher at the exam date. This procedure ensures structured and efficient organization of exams.

Batch grading. Sometimes a test or final project must be held outside an e-learning portal. Results of evaluation of these projects must be transferred to the e-learning portal, as they constitute a component of learning deliverables and can be processed automatically via the course evaluation algorithm. Portals have tools for batch copying of grades from a worksheet to portal users' accounts. These grades can be presented as scores, comments to a paper, or short pass/fail information.

This tool was used twice during the pathophysiology course: when a test was taken conventionally, and in cases of accepted complaints after an electronic test. The initial subject test was held on paper and its results (scores) were transferred to a portal, constituting part of course passing. For resolving complaints concerning electronic tests, an element called extra points was created in the course. In batch evaluation mode, the teacher would use it to add points for each question where a technical error occurred during the exam and the answer could not be saved in the portal.

To summarize, in order to carry out evaluation of students' knowledge with surveying in an e-learning portal in an efficient and optimized manner, the following tools are used:

- integrated test editors,

- batch evaluation of learning results (Bulk assessment),

- registration for test/exam dates (registration for groups),

- a portal user grouping mechanism.

Course management. Management of course organization, particularly distribution of information, is a very important element of teaching. It facilitates efficient course progress and supports communication between the participants of the learning process. This is particularly important if the classes are attended by a large group of participants (students) and knowledge providers (persons engaged in teaching the course). Information must be provided quickly, reach the right audience, and remain within the online course resources. The pathophysiology course was attended by 250 students in 10 learning groups as well as by 11 learning providers, taking their differ- 
ent roles during the course (chapter: Characteristics of Classes at a Medical School, points 8-11).

Recipients of information. All information, whether designed for individuals or for groups, should be presented in the portal in a location accessible only to the target group, i.e., in courses, group resources, or individual user account information. When information is maintained in elearning portal resources, it is easy to control and monitor, and course participants do not need to search for information concerning them directly. Students can easily find the information they need in e-learning portal resources.

Subscription for course changes. Every student should be informed on an ongoing basis of any news in their distance-learning course and in their group. The notification mechanism showing changes in the dynamic parts of the course is a very valuable functionality.

Subscription for changes in the pathophysiology course involves documents placed in file repositories (subject folders) and postings in discussion forums. Course participants should be directed to this portal function because they subscribe for course elements themselves. If they fail to do that, the utility will not work, and therefore the user will not receive news updates.

Another tool for reminding users about changes in the course is the Notifications tool. The teacher can use it to record information indicating a major change in the course. A message in the notification section is in text format, displayed to the user in passive mode after opening the message page. This tool is particularly useful if the given course component has no change subscription options, e.g. calendar.

Calendar. A distance course must have a precise calendar for covering specific portions of material, including deadlines for tests and exams. It seems natural to use the calendar function for this purpose. It allows students to check the progress of the course on an ongoing basis and prevents the omission of certain important events, such as final tests. It is convenient to include certain links to relevant course fragments and links to more detailed information, for example class rules or the course syllabus, in the calendar. Calendars can be included in e-learning portals as an element of the course, integrated with the student's account calendar.

Individual student achievement. This is a report from the portal's database, comprising information about the results achieved by the student. It is a very useful tool to enhance communication with students.

In summary, course management (distribution of information) is provided by the following tools in an e-learning portal: 
- calendar,

- notifications (static message page),

- subscriptions for dynamic course changes,

- ability to send information to a given group or selected group of users using group tools (e.g. contact form, discussion forum)

- individual list of course participants' achievements.

Archiving the learning results. All learning results are automatically archived in a single repository, which is the distance learning portal database. Backup copies of the database are produced by mechanisms controlled by the server administrator, while database integrity is assured through the implemented database system. Teachers will only have to make an efficient use of that repository. Other e-learning portal users, such as the course coordinator or selected administrative personnel (chapter: Characteristics of Classes at a Medical School, class participants specified in points 8-11), can receive permission to access information concerning learning results. An archive from the portal database can be transferred to external storage media if the teacher or course coordinator wants to gather such data locally.

In the case of the pathophysiology course, the most important data archived in the portal database are the following:

- test and exam results together with the students' papers,

- specification of partial scores for classes

- students' general scores,

- self-test results,

- division of participants into groups,

- survey results,

- forum discussions.

Some of this data can be used for statistical analysis to evaluate the course and learning results.

To summarize, the data archiving function in an e-learning portal employs the following tools:

- user grouping,

- portal database report (defined in the application for automatic generation),

- reports repository available to authorized accounts,

- creation of comprehensive course archives that can be uploaded to another portal instance database (e.g. in case of hardware change)

- creation of test archives

- reports on account performance in the prescribed interval. 


\section{Set of Tools Developed for Teaching Core Subject Classes at a Medical School - Final Conclusions}

On the basis of their analysis, the authors present a set of tools to be used while teaching distance education classes to students of a medical school (Table 1).

Table 1. E-learning portal tools for medical education - authors' proposal

\begin{tabular}{|c|c|c|}
\hline \multicolumn{3}{|c|}{$\begin{array}{l}\text { Division of portal application functions and a set of necessary e-learning portal tools } \\
\text { to execute those functions for the purpose of conducting classes with students of } \\
\text { a medical university - authors' proposal: }\end{array}$} \\
\hline & Portal application functions & \begin{tabular}{|c|} 
Tools \\
\end{tabular} \\
\hline $\mathrm{A}$ & $\begin{array}{l}\text { course distribution of learning } \\
\text { resources }\end{array}$ & $\begin{array}{l}\text { - folder (file repository) } \\
\text { - forum } \\
\text { - contact form (e-mail) } \\
\text { - testing (self-tests) } \\
\text { - user grouping }\end{array}$ \\
\hline $\mathrm{B}$ & communication & $\begin{array}{l}\text { - discussion forums } \\
\text { - contact form } \\
\text { - user grouping }\end{array}$ \\
\hline $\mathrm{C}$ & examination and surveying & $\begin{array}{l}\text { - test editors } \\
\text { - testing and surveying } \\
\text { - batch grading } \\
\text { - registration for test/exam dates } \\
\quad \text { (registration for groups) } \\
\text { - individual list of course participants' } \\
\text { achievements } \\
\text { - user grouping }\end{array}$ \\
\hline $\mathrm{D}$ & $\begin{array}{l}\text { managing course organization } \\
\text { (distribution of information) }\end{array}$ & $\begin{array}{l}\text { - calendar } \\
\text { - notifications } \\
\text { - subscription for notification of course } \\
\text { changes } \\
\text { - sending information: e-mail, forum } \\
\text { - individual list of course participants' } \\
\text { achievements }\end{array}$ \\
\hline $\mathrm{E}$ & archiving & $\begin{array}{l}\text { - user grouping } \\
\text { - creating tests and course archives } \\
\text { - repository of reports } \\
\text { - automatic generation }\end{array}$ \\
\hline $\mathrm{F}$ & group/user space & $\begin{array}{l}\text { - tools available to a group: } \\
\text { * contact form } \\
\text { * folder (group files repository) } \\
\text { * forum } \\
\text { - user tools: } \\
\text { * directory } \\
\text { * notepad } \\
\text { * list of achievements } \\
\text { * subscription for changes in course } \\
\text { elements } \\
\text { * portal user search engine }\end{array}$ \\
\hline
\end{tabular}


In the last row of Table 1, the authors present tools assigned to a group of students and to an individual user. The group of pathophysiology course students evaluated for the purpose of making these recommendations had a shared disk space (directory), communication tools (forum, e-mail), and contact information for their group members. The directory facilitated data exchange among group members and constituted a sort of group work archive. This is especially important when group work is evaluated. Apart from group tools and functional course tools (A-E), each portal user can use the utilities for his individual account, as shown under item $\mathrm{F}$ in Table 1.

\section{Distance Course Evaluation Results}

Evaluation of distance courses in the opinion of students of the Poznan University of Medical Sciences. In this chapter, the authors present the results of surveys following completion of the pathophysiology course for second-year medical students during the 2013-2014 and 2014-2015 academic years. Four hundred and one students participated in the survey, of which 155 participated in 2013-2014 and 246 in 2014-2015.

Survey results were statistically analyzed using the Mann-Whitney $\mathrm{U}$ test. Calculations were carried out at a statistical significance level of $\alpha=0.05$ in STATISTICA v. 10.0 from StatSoft.

The proposed set of tools used in the distance course were assessed for their usefulness. The students would grade this aspect according to a fivegrade scale: $0,1,2,3,4$, where 4 means that the tools were very useful for the course and 0 means that they were definitely not useful (Figure 1). The significant difference $(p<0.05)$ in results between the analyzed groups may be related to the fact that the pathophysiology course in 2013-2014 was the first class using an e-learning portal, which acquainted students with the broad possibilities of e-learning tools.

Then, the aspect of technical handling of tools in the e-learning portal was evaluated. Zero (0) signifies that the given student had no problem with using the tools and 3 means that this person was completely unable to use them (Figure 2). The significant difference $(p<0.05)$ in results between the analyzed groups may be related the fact that the course offered in 2014-2015 used more e-learning portal tools compared with the 20132014 course.

The students were asked whether they would like such distance courses to be available for other subjects as well. A response of 4 means that they 


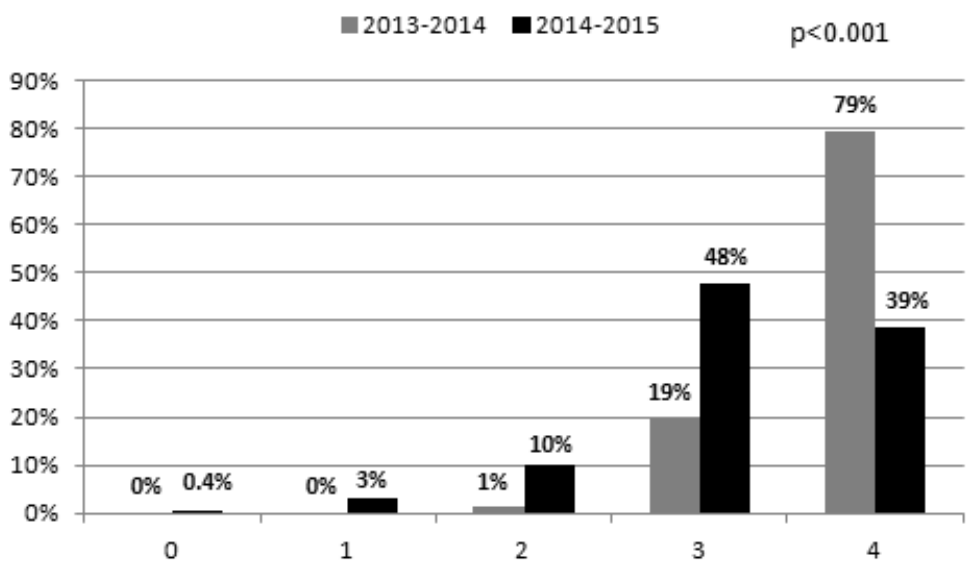

Figure 1. Usefulness of e-learning portal tools

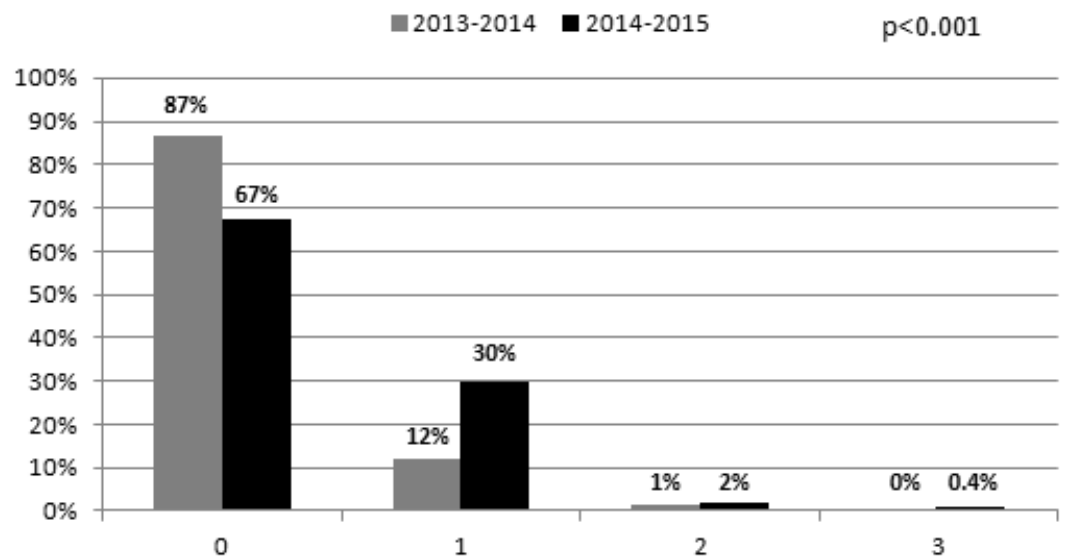

Figure 2. Technical handling of tools in the e-learning portal

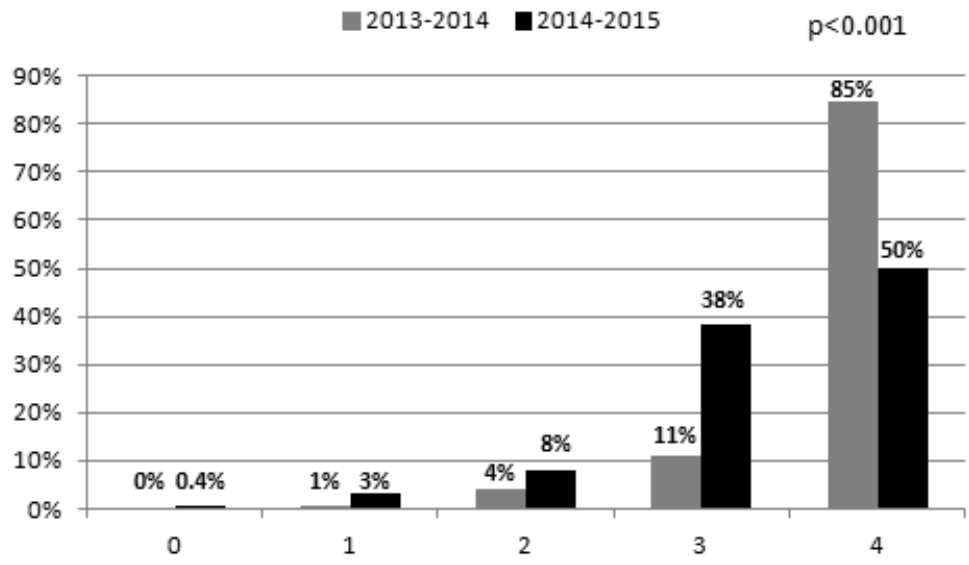

Figure 3. Distance courses in the future 
definitely would and 0 means a complete lack of acceptance - definitely not (Figure 3). The significant difference $(p<0.05)$ in the results between the analyzed groups - greater enthusiasm of the students in 2013-2014 may be related the fact that they were the first group of students who had pathophysiology classes using a remote course and were participants in the only classes held remotely during the second year of study.

Evaluation of distance courses in the opinion of students of the Medical University of Bialystok. E-learning courses were held in therapeutic massage for students of the Faculty of Physiotherapy, and in obstetrics, gynecology, and gynecological and obstetric nursing for students of the Faculty of Obstetrics. After completion of the course, an evaluation survey was given concerning:

1. Effects in terms of understanding the academic content and consolidation of the acquired knowledge.

2. Evaluation of the level of satisfaction with the completed course (the most valuable and the most problematic elements of this learning format).

In Table 2 the authors present part of the course evaluation process results (Półjanowicz et. al., 2012, 2014).

Table 2. Opinion of students of the Medical University of Bialystok

\begin{tabular}{|l|c|c|}
\hline \multicolumn{1}{|c|}{ Issues mentioned } & $\begin{array}{c}\text { Therapeutic } \\
\text { Massage } \\
\text { N=44 }\end{array}$ & $\begin{array}{c}\text { Obstetrics, Gynecology, } \\
\text { and Gynecological and } \\
\text { Obstetric Nursing } \\
\text { N=47 }\end{array}$ \\
\hline technical problems with operating e-learning portal & $0 \%$ & $9 \%$ \\
\hline $\begin{array}{l}\text { acceptance of e-learning portal tools used during } \\
\text { the course }\end{array}$ & $89 \%$ & $98 \%$ \\
\hline $\begin{array}{l}\text { willingness to learn subject content using online } \\
\text { methods }\end{array}$ & $74 \%$ & $82 \%$ \\
\hline e-learning as a positive experience & $92 \%$ & $78 \%$ \\
\hline $\begin{array}{l}\text { the helpfulness of the distance course in terms of } \\
\text { understanding the covered issues better }\end{array}$ & $72 \%$ & $76 \%$ \\
\hline $\begin{array}{l}\text { the positive effect of distance learning on knowledge } \\
\text { consolidation }\end{array}$ & $78 \%$ & $88 \%$ \\
\hline $\begin{array}{l}\text { the helpfulness of using distance methods to prepare } \\
\text { for the exam }\end{array}$ & $86 \%$ & $90 \%$ \\
\hline $\begin{array}{l}\text { positive influence of distance courses on the school's } \\
\text { image }\end{array}$ & $88 \%$ & \\
\hline
\end{tabular}


The results of the surveys from both medical schools confirm that the tools used in remote courses have met their targets and work well in medical education.

\section{Conclusions}

A teacher running a distance course at a medical school with the use of e-learning or blended learning methods should consider using the following set of tools (the authors' proposal):

1. Calendar.

2. Notifications.

3. Subscription for course changes.

4. Folder (file repository).

5. Forum.

6. Contact form (e-mail).

7. Registration for groups.

8. User grouping mechanism.

9. Test editors.

10. Batch grading.

11. Individual list of achievements.

12. Archiving with the ability to transfer data to another portal.

13. Ability to assign tools to a specific group.

The proposed set of tools offers the following benefits to the institution in charge of medical education:

- convenience for participants in the learning process,

- streamlining and optimization of teachers' work,

- easy, quick, and safe access to resources and learning deliverables,

- higher security of data,

- more communication options,

- more efficient flow of information,

- highly efficient class organization.

According to the authors, the proposed set of tools is optimized for teaching basic science courses at a medical university. These conclusions are supported by the opinions of students who accepted the distance course methodology and rated it very highly.

Further changes in course structure could involve application of other communication tools than the standard set, such as e-mail or forum capabilities. It would be reasonable to consider extending the course with tools for implementing team work on the portal (Roszak et al., 2014), which 
is not an easy task in class. This will be the next step of the authors' research.

Medical universities' environments are specific and cannot be compared with technical universities or social science universities due to their slightly different needs and opportunities.

The authors of the article emphasize the need to pursue continuous training to improve the skills and ICT competences of the teaching staff involved in teaching the courses. Thus, success of the applied distance learning strategy is a function of the e-learning portal tools and the ICT and teaching skills of the persons who use them (Kołodziejczak et al., 2014; Ren-Kurc et al., 2012).

Finally, it should be pointed out that together with implementation of distance learning, a decision is made to select a specific educational portal. This is an essential decision because it determines further pursuit of learning goals through the use of appropriate tools available on the portal. An e-learning portal must meet a number of capacity and functionality requirements according to the characteristics of the given type of education.

\section{R E F E R E N C E S}

Clarke, A. (2007). E-learning nauka na odległość. Warszawa, Polska: WKŁ.

Hyla, M. (2012). Przewodnik po e-learningu. Warszawa, Polska: Wolters Kluwer.

IMS Question and Test Interoperability (v.2.1 Final Specification). Retrieved from: http://www.imsglobal.org/question/index.html\#version2.1

Kołodziejczak, B., Roszak, M., Kowalewski, W., Ren-Kurc, A., \& Bręborowicz, A. (2014). Participants academic distance education - Case study. Technics Technologies Education Management, 10(2), 242-249.

Meger, Z. (2010). Tendencje współczesnej edukacji - od a-Learning do z-Learning. In L. Banachowski (Ed.), Postepy e-edukacji (pp. 16-25). Warszawa, Polska: Wydawnictwo PJWSTK.

Półjanowicz, W., Latosiewicz, M., \& Terlikowski, J. (2012). The results of teaching of subject "Obstetrics, gynecology and gynecological and obstetric nursing" with the use of e-learning platform at the Faculty of Health Sciences, Medical University of Bialystok. Studies in Logic, Grammar and Rhetoric. Logical, Statistical and Computer Methods in Medicine, 29(42), 181-192.

Półjanowicz, W. (2014). Efektywność zdalnej edukacji w aspekcie nauczania przedmiotów medycznych. In M. Dąbrowski, \& M. Zając (Eds.), E-edukacja w praktyce - wyzwania i bariery (pp. 89-104). Warszawa, Polska: Fundacja Promocji i Akredytacji Kierunków Ekonomicznych. 
Półjanowicz, W., Roszak, M., Kołodziejczak, B., \& Bręborowicz, A. (2014). An analysis of the effectiveness and quality of e-learning in medical education. In E. Smyrnova-Trybulska (Ed.), E-learning and Intercultural Competences Development in Different Countries (pp. 177-196). KatowiceCieszyn, Poland: Studio Noa.

Ren-Kurc, A., Kowalewski, W., Roszak, M., \& Kołodziejczak, B. (2012). Building Digital Content for E-Learning. Information and Communication Technologies (ICT) Competence. In E. Smyrnova-Trybulska (Ed.), E-learning for Societal Needs (pp. 201-212). Katowice-Cieszyn, Poland: Studio Noa.

Roszak, M., Kołodziejczak, B., Kowalewski, W., \& Ren-Kurc, A. (2014). Academic blended learning - competences and tools. International Journal of Continuing Engineering Education and Life-Long Learning, 24(3/4), 286-301.

Roszak, M., Kołodziejczak, B., Kowalewski, W., \& Ren-Kurc, A. (in press). Implementation of e-learning portal for academic education and lifelong learning. International Journal of Continuing Engineering Education and Life-long Learning.

Smyrnova-Trybulska, E. (2009). About some basic aspects of distance learning. In E. Smyrnova-Trybulska (Ed.), Theoretical and practical aspects of distance learning, Collection of Scholarly Papers (pp. 13-35). Cieszyn, Poland: Visegrad Fund. 